\title{
SATURASI OKSIGEN PADA PETUGAS DI TERMINAL YANG TERPAPAR KARBON MONOKSIDA UDARA
}

\author{
Katerina Kanthi Rosari, Junaidi, Zulfikar Ali As \\ Poltekkes Kemenkes Banjarmasin Jurusan Kesehatan Lingkungan \\ E-mail: katarinakanti14@gmail.com
}

\begin{abstract}
Oxygen Saturation In Officers In Terminals Exposed With Air Monoxide Carbon. Monoxide (CO) bonds with blood are 200 times stronger than oxygen bonds with blood. When inhaled $\mathrm{CO}$ will be absorbed through the lungs following the blood circulation and binds to haemoglobin to form $\mathrm{HbCO}$ in the tissues which will block the entry of oxygen needed by the body. The purpose of this study was to determine the relationship of air CO levels with oxygen saturation $\left(\mathrm{SpO}_{2}\right)$ in officers in Terminal Type $\mathrm{B}$ of South Kalimantan Province. This type of research is analytically using a cross-sectional design with a sample of 24 people. Data collection was carried out by interview, observation, CO measurement and SpO2 examination with Pulse Oximetry. The results showed that there was a relationship between air CO levels and the $\mathrm{SpO}_{2}$ of terminal officers with a significance value of 0.0025 (sig. <0.05). Even though the air CO level in the field is still far below the threshold, but the SpO2 level of officers is not healthy, the smoking habits of terminal officers cause it in the workspace, and the field with the number of cigarettes smoked as many as 11-20 cigarettes per day. There are more than 20 sticks per day, so prevention efforts are needed by providing and using PPE (Personal Protective Equipment) for terminal staff in the form of masks and striving for the terminal team to stop smoking.
\end{abstract}

Keywords: Carbon Monoxide (CO); Oxygen Saturation (SPO $)$

\begin{abstract}
Abstrak: Saturasi Oksigen Pada Petugas Di Terminal Yang Terpapar Karbon Monoksida Udara. Ikatan monoksida (CO) dengan darah lebih kuat 200 kali dari pada ikatan oksigen dengan darah. CO apabila terhirup akan diabsorbsi melalui paru-paru mengikuti peredaran darah dan berikatan dengan haemoglobin membentuk HbCO dalam jaringan yang akan menghalangi masuknya oksigen yang dibutuhkan oleh tubuh. Tujuan penelitian ini adalah untuk mengetahui hubungan kadar $\mathrm{CO}$ udara dengan saturasi oksigen ( $\mathrm{SpO}_{2}$ ) pada petugas di Terminal Tipe B Provinsi Kalimantan Selatan. Jenis penelitian ini adalah analitik menggunakan desain cross sectional dengan jumlah sampel 24 orang. Pengumpulan data dilakukan dengan wawancara, observasi, pengukuran $\mathrm{CO}$ dan pemeriksaan $\mathrm{SpO}_{2}$ dengan Pulse Oksimetri. Hasil penelitian menunjukan bahwa ada hubungan antara kadar CO udara dengan $\mathrm{SpO}_{2}$ petugas terminal dengan nilai signifikasi 0.0025 (sig. <0,05). Walaupun kadar CO udara di lapangan masih jauh di bawah ambang batas tetapi kadar $\mathrm{SpO}_{2}$ petugas termasuk tidak normal, hal tersebut disebabkan karena adanya kebiasaan merokok petugas terminal di ruang kerja maupun lapangan dengan jumlah rokok yang dihisap sebanyak 11-20 batang perhari dan ada yang lebih dari 20 batang perharinya, sehingga diperlukan upaya pencegahan dengan penyediaan dan penggunaan APD (Alat Pelindung Diri) untuk petugas terminal berupa masker dan mengupayakan agar petugas terminal bisa berhenti merokok.
\end{abstract}

Kata Kunci: Karbon Monoksida (CO); Saturasi Oksigen (SpO $)$

\section{PENDAHULUAN}

Sumber utama dari karbon monoksida (CO) adalah asap knalpot kendaraan terutama mesin berbahan bakar bensin. Sudah sejak lama diketahui bahwa gas CO dalam jumlah banyak (konsentrasi tinggi) dapat menyebabkan gangguan kesehatan bahkan juga dapat menimbulkan kematian $^{[1]}$. Ikatan CO dengan darah (karboksihemoglobin) lebih stabil daripada ikatan oksigen dengan darah (oksihemoglobin). Keadaan ini menyebab-kan darah menjadi lebih mudah menangkap gas CO dan menyebabkan fungsi vital darah sebagai pengangkut oksigen terganggu[2]. 
Terminal merupakan salah satu lokasi yang tinggi pencemaran udaranya, karena terminal merupakan pusat kegiatan yang memerlukan jasa transportasi, di samping itu terminal merupakan tempat aktivitas manusia baik pengelola terminal, pedagang dan pemakai jasa. Adanya aktivitas kendaraan bermotor yang setiap hari dan dalam waktu 24 jam tersebut akan memicu adanya pencemaran udara di lingkungan terminal.

Berdasarkan data tiga bulan terakhir emisi CO tiap kendaraan umum di Kota Banjarmasin sebesar 0,02 \% - 2,8\% dengan CO maksimal yaitu $4,5 \%{ }^{[3]}$. Walaupun emisi CO kendaraan umum dengan hasil tersebut masih dibawah NAB, tetapi jumlah kendaraan yang ada di Terminal Tipe B Provinsi Kalimantan Selatan dengan sebanyak 42-154 buah/hari, memungkinkan CO udara ambien di terminal terakumulasi.

Penelitian terdahulu tentang saturasi oksigen pada subjek yang terpajan CO melalui asap rokok diperoleh saturasi oksigen responden terbanyak adalah perokok derajat ringan $(63,33 \%)$ dengan saturasi oksigen rata-rata 98,37. Perokok derajat sedang memiliki saturasi oksigen rata-rata 97,86 sedangkan perokok derajat berat 96,25. Seluruh responden memiliki saturasi oksigen rata-rata 97,97. Seluruh responden masih termasuk kategori saturasi oksigen baik (95-100\%). Disimpulkan bahwaterdapat hubungan yang signifikan antara merokok dengan saturasi oksigen. Semakin berat derajat merokok maka semakin rendah kadar saturasi oksigen dalam darah ${ }^{[4]}$.

Pada penyelenggaraan terminal penumpang angkutan jalan memiliki potensi tinggi gangguan kesehatan salah satunya dapat mengalami turunnya kapasitas angkut oksigen akan menaikkan derajat hipoksia ataupun keracuan pada petugas di Terminal Tipe B Provinsi Kalimantan Selatan karena terpapar berupa gas CO. Faktor penting yang menentukan pengaruh $\mathrm{CO}$ terhadap tubuh manusia adalah konsentrasi $\mathrm{HbCO}$ yang terdapat di dalam darah. Bila $\mathrm{O}_{2}$ berikatan dengan HbCO maka reaksi tersebut tidak reversibel, sehingga jumlah $\mathrm{Hb}$ yang tersedia untuk transpor $\mathrm{O}_{2}$ berkurang.

\section{BAHAN DAN CARA PENELITIAN}

Jenis penelitian ini adalah analitik menggunakan desain cross-sectional, yaitu data yang menyangkut variabel bebas (kadar CO udara) dan variabel terikat (saturasi oksigen) akan dikumpulkan dalam waktu yang bersamaan dan secara langsung dengan variabel pengganggu adalah merokok. Populasi dalam penelitian ini adalah seluruh petugas di Terminal Tipe B Provinsi Kalimantan Selatan. Sampel pada penelitian ini menjadi 12 orang yang terpajan di lapangan (Shift 1 dan 2) dan 12 orang yang tidak terpajan di ruang kerja. Pada pengukuran kadar CO di lapangan dilaksanakan $2 \mathrm{x}$ pengukuran berdarakan shift kerja di lapangan dan $1 \mathrm{x}$ pengukurn di ruang kerja dengan waktu ukur yaitu tengah periode sebagai rata-rata kondisi CO di lokasi. Metode alat pengukuran Gas Analizer dengan justifikasi terhadap perbedaan jumlah kendaraan angkutan, arah angin, suhu, kelembaban, kecepatan udara akan menghasilkan kadar CO udara yang berbeda. Pengukuran saturasi oksigen saturasi oksigen $\left(\mathrm{SpO}_{2}\right)$ dilakukan dengan waktu ukur yaitu setelah lama paparan CO udara saat bekerja dengan alat Pulse Oximetry. Data hasil penelitian diolah menggunakan analisis statistik yaitu uji $C h i$ Square.

\section{HASIL PENELITIAN DAN PEMBAHASAN}

Terminal Tipe B Provinsi Kal-Sel merupakan aktivitas keluar masuk kendaraan bermotor yaitu jenis AKDP (Antar Kota Dalam Provinsi), ANGKOT (Angkutan Perkotaan) dan AKAP (Angkutan Kota Antar Provinsi) dengan jumlah kendaraan sebanyak 42-154 buah/hari. Menurut observasi semua petugas terminal di lapangan tidak menggunakan masker atau pun APD dan beresiko terpapar gas CO selama 6 jam per hari.

Berdasarkan hasil penelitian diketahui karakteristik petugas di Terminal Tipe B Provinsi Kalimantan Selatan dapat dilihat pada Tabel 1 sebagai berikut: 
Katerina Kanthi Rosari, Junaidi, Zulfikar Ali As,

Tabel 1. Karakteristik Petugas di Terminal Berdasarkan Kebiasaan Merokok

\begin{tabular}{ccccccc}
\hline $\begin{array}{c}\text { Kebiasaan } \\
\text { merokok } \\
\text { (batang/hari) }\end{array}$ & $\begin{array}{c}\text { Ruang Kerja } \\
\text { Jumlah } \\
(\text { Org) }\end{array}$ & $\begin{array}{c}\text { Persentase } \\
(\%)\end{array}$ & $\begin{array}{c}\text { Lapangan (Shift 1) } \\
\text { Jumlah }\end{array}$ & $\begin{array}{c}\text { Persentase } \\
\text { Lrg) }\end{array}$ & $\begin{array}{c}\text { Lapangan (Shift 2) } \\
\text { Jumlah }\end{array}$ & $\begin{array}{c}\text { Persentase } \\
(\%)\end{array}$ \\
\hline 0 & 2 & 17 & 2 & 33 & 3 & 50 \\
$1-10$ & 8 & 67 & 1 & 17 & - & - \\
$11-20$ & 1 & 8 & 2 & 33 & 2 & 33 \\
$>20$ & 1 & 8 & 1 & - & 1 & 17 \\
Jumlah & 12 & 100 & 6 & 100 & 6 & 100 \\
\hline
\end{tabular}

Karakteristik petugas terminal berdasarkan kebiasaan merokok antara 110 batang/hari di ruang kerja berjumlah 8 orang (67\%). Sedangkan kebiasaan merokok antara 1-10 batang/hari dilapangan (shift 1) berjumlah 2 orang dengan persentase 33\% dan kebiasaan merokok 0 batang/hari di lapangan (shift
2) berjumlah 3 orang dengan persentase $50 \%$.

Hasil uji statistik dengan menggunakan Chi Square terdapat hubungan kebiasaan merokok dengan saturasi oksigen pada petugas di Terminal Tipe B Provinsi Kalimantan Selatan berkolerasi karena nilai sig. 0.004 (sig. < $0,05)$.

Tabel 2. Karakteristik Petugas di Terminal Berdasarkan Keluhan yang Timbul selama Kerja

\begin{tabular}{|c|c|c|c|c|c|c|}
\hline \multirow{3}{*}{$\begin{array}{c}\text { Keluhan } \\
\text { timbul } \\
\text { selama kerja }\end{array}$} & \multicolumn{6}{|c|}{ Petugas } \\
\hline & \multicolumn{2}{|c|}{ Ruang Kerja } & \multicolumn{2}{|c|}{ Lapangan (Shift 1) } & \multicolumn{2}{|c|}{ Lapangan (Shift 2) } \\
\hline & $\begin{array}{c}\text { Jumlah } \\
\text { (Org) }\end{array}$ & $\begin{array}{c}\text { Persentase } \\
(\%)\end{array}$ & $\begin{array}{c}\text { Jumlah } \\
\text { (Org) }\end{array}$ & $\begin{array}{c}\text { Persentase } \\
(\%)\end{array}$ & $\begin{array}{c}\text { Jumlah } \\
\text { (Org) }\end{array}$ & $\begin{array}{c}\text { Persentase } \\
(\%)\end{array}$ \\
\hline Pusing & 6 & 50 & 4 & 44 & 2 & 40 \\
\hline Mual & 2 & 17 & 1 & 14 & 1 & 20 \\
\hline Batuk & 2 & 17 & 1 & 14 & 1 & 20 \\
\hline Nyeri Dada & 2 & 17 & 3 & 33 & 1 & 20 \\
\hline Jumlah & 12 & 100 & 9 & 100 & 5 & 100 \\
\hline
\end{tabular}

Karakteristik petugas terminal berdasarkan keluhan yang timbul selama bekerja mengeluh pusing di ruang kerja dengan persentase $50 \%$, di lapangan (shift 1) dengan persentase $44 \%$ dan di lapangan (shift 2) dengan persentase $40 \%$.

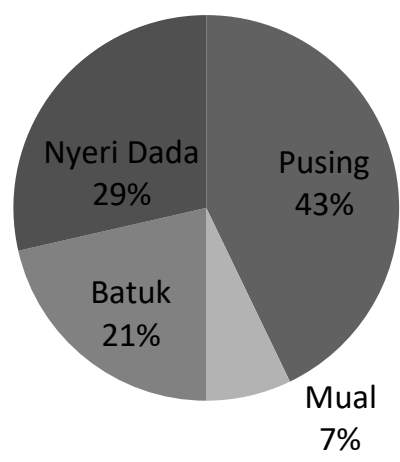

Gambar 1. Karakteristik Petugas Di Terminal Berdasarkan Keluhan Petugas yang dengan $\mathrm{SpO}_{2}$ Tidak Normal 
Karakteristik petugas terminal berdasarkan keluhan $\mathrm{SpO}_{2}$ tidak normal sebagian besar mengeluh pusing dan nyeri dada.

Tabel 4. Kadar CO Udara di Terminal

\begin{tabular}{clccc}
\hline NO. & Lokasi Pengukuran & Hasil Pengujian & $\begin{array}{c}\text { NAB } \\
\text { (PER.13/MEN/X/2011) }\end{array}$ & Ket. \\
\hline 1. & Ruang Kerja & $670 \mu \mathrm{g} / \mathrm{Nm}^{3}$ & $28.629 \mu \mathrm{g} / \mathrm{Nm}^{3}$ & $\mathrm{MS}$ \\
2. & Lapangan (shift 1) & $1.500 \mu \mathrm{g} / \mathrm{Nm}^{3}$ & & $\mathrm{MS}$ \\
3. & Lapangan (shift 2) & $1.500 \mu \mathrm{g} / \mathrm{Nm}^{3}$ & & MS \\
\hline
\end{tabular}

Kadar CO udara di Terminal Tipe B provinsi Kalimantan Selatan masih dibawah nilai ambang batas dikarenakan karbon monoksida mempunyai kecenderungan terakumulasi di dekat sumber, tetapi mudah terdispersi sehingga konsentrasinya di udara bebas dapat mengencer dengan cepat. CO dapat menyebabkan masalah pencemaran udara dalam ruang (indoor air pollution). Penelitian hubungan kadar kadar monoksida (CO) udara terhadap tingkat kewaspadaan petugas parkir di berbagai jenis tempat parkir[5], juga menunjukkan kadar CO udara di tempat parkir tertutup (13,86 ppm) lebih tinggi dari pada di tempat parkir terbuka $(1,96 \mathrm{ppm})$ dan tempat parkir semi terbuka $(2,32 \mathrm{ppm})$. Hal ini membuktikan bahwa hasil pengukuran kadar CO udara lapangan (terpapar) di dapatkan di titik sumber pencemar di terminal masih jauh dari di bawah nilai ambang batas, karena lokasi luar terminal lebih terbuka walupun sumber pencemar kendaraan dalam kondisi Idle (diam), CO (Karbonmonoksida) yang dihasilkan dari gas buangnya lebih besar 4-6\% dan kondisi berjalan normal 1-4\%[6].

Kadar CO udara di ruang kerja lebih rendah dari kadar CO udara di lapangan dikarenakan lokasi ruang kerja berjarak jauh dari sumber pencemar dan berada pada lantai 2 sehingga kadar CO udara lebih rendah karena tidak terakumulasi walaupun pada ruang tertutup. Adanya kadar CO udara di ruang kerja sebesar 670 $\mu \mathrm{g} / \mathrm{Nm}^{3}$ dikarenakan adanya aktivitas merokok karyawan selama bekerja berdasarkan hasil obeservasi. Adapun faktor yang mempengaruhi kadar CO udara di terminal yaitu arah angin, suhu, kelembaban, kecepatan udara, jumlah kendaraan angkutan dan kendaraan dijalan raya terlintas di wilayah Terminal Tipe B Provinsi Kalimantan Selatan dapat dilihat pada tabel 5.

Tabel 5. Faktor yang Mempengaruhi Kadar CO Udara di Terminal

\begin{tabular}{|c|c|c|c|c|c|}
\hline No. & Pengukuran Lokasi & Satuan & Ruang Kerja & $\begin{array}{l}\text { Lapan } \\
\text { Shift } 1\end{array}$ & Shift 2 \\
\hline 1. & Waktu pengukuran & WITA & 12.30 & 11.00 & 15.30 \\
\hline 2. & Perkiraan luas tempat pengukuran & $\mathrm{m} 2$ & 100 & 3.000 & 3.000 \\
\hline 3. & $\begin{array}{l}\text { Perkiraan jumlah kendaraan masuk, } \\
\text { keluar dan melintas di wilayah terminal }\end{array}$ & Buah & 3.207 & 3.771 & 3.960 \\
\hline 4. & Arah angin & - & $\begin{array}{l}\text { Timur ke } \\
\text { Barat }\end{array}$ & $\begin{array}{l}\text { Timur ke } \\
\text { Barat }\end{array}$ & Selatan \\
\hline 5. & Kecepatan angin & $\mathrm{m} / \mathrm{s}$ & 0,5 & 1,5 & 1,5 \\
\hline 6. & Suhu & ${ }^{\circ} \mathrm{C}$ & 30 & 32,6 & 32,8 \\
\hline 7. & Kelembaban & $\%$ & 64 & 52 & 52 \\
\hline
\end{tabular}

Jumlah kendaraan masuk, keluar dan melintas terbanyak 3.960 buah, dengan kecepatan angin maksimum 1,5 $\mathrm{m} / \mathrm{s}$. Suhu maksimum sebesar $32,8{ }^{\circ} \mathrm{C}$ dan kelembaban sebesar 52\%. 
Katerina Kanthi Rosari, Junaidi, Zulfikar Ali As,

Tabel 6. Kadar Saturasi Oksigen $\left(\mathrm{SpO}_{2}\right)$ Petugas di Terminal

\begin{tabular}{cccccccc}
\hline $\begin{array}{c}\text { Saturasi } \\
\text { Oksigen } \\
\text { (Sp02) }\end{array}$ & $\begin{array}{c}\text { Rumlah } \\
\text { (Org) }\end{array}$ & $\begin{array}{c}\text { Persentase } \\
(\%)\end{array}$ & $\begin{array}{c}\text { Lapangan (Shift 1) } \\
\text { Jumlah } \\
\text { (Org) }\end{array}$ & $\begin{array}{c}\text { Persentase } \\
(\%)\end{array}$ & $\begin{array}{c}\text { Lapangan (Shift 2) } \\
\text { Jumlah } \\
\text { (Org) }\end{array}$ & $\begin{array}{c}\text { Persentase } \\
(\%)\end{array}$ & $\begin{array}{c}\text { Jumlah } \\
\text { (Org) }\end{array}$ \\
\hline $\begin{array}{c}\text { Normal } \\
\geq 95 \%\end{array}$ & 11 & 92 & 3 & 50 & 3 & 50 & 17 \\
$\begin{array}{c}\text { Tidak normal } \\
<95 \%\end{array}$ & 1 & 8 & 3 & 50 & 3 & 50 & 7 \\
Jumlah & 12 & 100 & 6 & 100 & 6 & 100 & 24 \\
\hline
\end{tabular}

$\mathrm{SpO}_{2}$ petugas di terminal normal $\geq$ 95\% berjumlah 11 orang di ruang kerja dengan persentasi $92 \%$. Sedangkan $\mathrm{SpO}_{2}$ petugas di terminal tidak normal $<95 \%$ berjumlah 3 orang di lapangan (shift 1 dan 2) dengan persentase $50 \%$.

Tabel 7. Tabulasi Silang CO udara dengan Saturasi Oksigen (SpO2)

\begin{tabular}{ccccc}
\hline & & \multicolumn{2}{c}{ Sp02 } & Total \\
& & Normal & $\begin{array}{c}\text { Tidak } \\
\text { normal }\end{array}$ & 12 \\
\hline \multirow{2}{*}{ Ruang kerja } & Ruang kerja & 11 & 1 & 12 \\
& Lapangan & 6 & 6 & 24 \\
\hline
\end{tabular}

$\mathrm{SpO}_{2}$ pada petugas di terminal normal sebanyak 17 orang dan tidak normal sebanyak 7 orang. Hasil uji statistik dengan menggunakan uji Chi Square terlihat nilai Asimp. Sig sebesar 0,025. Karena nilai Asimp. Sig $<0,05$ maka dapat disimpulkan "Ada hubungan yang signifikan antara $\mathrm{CO}$ udara dengan $\mathrm{SpO}_{2}$ pada petugas di Terminal Tipe B Provinsi Kalimantan Selatan. Hal ini dapat diartikan pula bahwa CO udara mempunyai kolerasi dengan $\mathrm{SpO}_{2}$ pada petugas di terminal. Hipoksemia terjadi ketika tingkat oksigen dalam darah di bawah 90\%. Ketika ini terjadi, orang mengalami sesak napas segera, karena tubuh mencoba untuk meningkatkan tingkat oksigen dalam tubuh. Kandungan oksigen dalam darah, merupakan indikasi dari gangguan yang mendasarinya. Berdasarkan tabel 6. $\mathrm{SpO}_{2}$ pada petugas terminal masih digolongkan hipoksemia ringan karena dinyatakan pada keadaan $\mathrm{SpO}_{2}$ 90-94\%.

Kemampuan darah untuk mentranspor oksigen menjadi berkurang, sehingga melemahkan kontraksi jantung dan menurunkan volume darah yang didistribusikan atau hipoksia jaringan. Kadar $\mathrm{COHb}$ darah di atas 60\% dapat menyebabkan kematian, sekitar (30-40)\% dapat menyebabkan pusing-pusing, keletihan dan pingsan[7]. Hal ini dibutikan petugas terminal sebagian besar mengeluh pusing dapat dilihat pada tabel 2 .

Walaupun kadar CO udara di lapangan masih jauh di bawah ambang batas dan kadar $\mathrm{SpO}_{2}$ petugas tidak normal dikarenakan pengaruh kebiasaan merokok terminal di ruang kerja maupun lapangan sebanyak 11- 20 batang dan $>20$ batang perharinya. Faktor yang mempengaruhi karboksihemoglobin ( $\mathrm{HbCO}$ ) tergantung derajat pajanan gas $\mathrm{CO}$ seperti kebiasaan merokok. Kebiasaan merokok membuat ikatan oksigen terhadap $\mathrm{Hb}$ pada kehadiran karbon monoksida menyebabkan menjadi sulitnya lepas $\mathrm{O}_{2}$ dari $\mathrm{Hb}$ pada kapiler-kapiler otot, dan juga mempersulit pergeseran kurva disosiasi kekiri dan dengan demikian menurunkan pemakaian $\mathrm{O}_{2}$.

Orang yang merokok akan mengeluarkan asap rokok yang mengandung gas CO dengan konsentrasi yang tinggi. Konsentrasi gas $\mathrm{CO}$ yang tinggi di dalam asap rokok menyebabkan kandungan $\mathrm{COHb}$ dalam darah orang yang merokok jadi meningkat. Keadaan ini tentu sangat 
membahayakan bagi kesehatan orang yang merokok. Orang yang merokok dalam waktu yang cukup lama (perokok berat) konsentrasi $\mathrm{COHb}$ dalam darahnya sekitar 6,9\%. Karboksihemoglobin tidak mampu membawa oksigen sehingga suplai oksigen jaringan terganggu ${ }^{[8]}$.

Hal in dibuktikan berdasarkan uji satitistik tabel 1 dan hasil $\mathrm{SpO}_{2}$ petugas terminal yang tidak normal memiliki latarbelakang kebiasaan merokok petugas terminal di ruang kerja maupun lapangan sebanyak 11- 20 batang dan $>20$ batang perharinya.

\section{KESIMPULAN DAN SARAN}

Berdasarkan hasil penelitian dapat disimpulkan "Ada hubungan yang signifikan antara $\mathrm{CO}$ udara dengan $\mathrm{SpO}_{2}$ pada petugas di Terminal Tipe B Provinsi Kalimantan Selatan. Hal ini dapat diartikan pula bahwa kadar CO udara mempunyai kolerasi dengan $\mathrm{SpO}_{2}$ pada petugas di terminal. Walaupun kadar CO udara di lapangan masih jauh di bawah ambang batas dan kadar $\mathrm{SpO}_{2}$ petugas tidak normal hal tersebut dikarenakan pengaruh kebiasaan merokok terminal di ruang kerja maupun lapangan sebanyak 11- 20 batang dan $>20$ batang perharinya, sehingga diperlukan upaya pencegahan dengan penyediaan dan penggunaan APD (Alat Pelindung Diri) untuk petugas terminal dengan penggunaan masker serta berhenti dari kebiasaan merokok.

\section{KEPUSTAKAAN}

1. Sarudji D., (2004) Faktor-faktor yang berpengaruh terhadap konsentrasi Karbon Monoksida (CO) di udara ambien di atas jalan-jalan raya Kota Surabaya. Jurnal Ilmiah INOVASI, Edisi Mei, 2004. Vol. XII. No. 2

2. Zuhriyah N.E., (2008) Analisis Kadar Karboksihemoglobin (COHb) dan Dampaknya Terhadap Kesehatan Pekerja Bengkel. skripsi. Universitas Islam Negeri (UIN) Malang, Fakultas Sains dan Teknologi, Jurusan Biologi

3. Dinas Perhubungan Kota Banjarmasin (2017). Data tiga bulan terakhir emisi CO. Kota Banjarmasin
4. Septia Nindirah, Wungouw Herlina, Doda Vannda, (2016), Hubungan Merokok Dengan Saturasi Oksigen Pada Pegawai Di Fakultas Kedokteran Universitas Sam Ratulangi Manado, Universitas Sam Ratulangi Manado

5. Gunawan, (2009). Hubungan Kadar Karbon Monoksida (CO) Udara Terhadap Tingkat Kewaspadaan Petugas Parkir Di Berbagai Jenis Tempat Parkir. KTI Fakultas Kedokteran Universitas Kristen Maranatha Bandung

6. Widayani, (2004). Kajian Korelasi Tingkat Kepadatan Lalu Lintas Di Kota Semarang Terhadap Konsentrasi CO Dan Pb Dengan Model Gaussian. Thesis. Universitas Diponegoro.

7. Subhi, Misbahul (2013). Pengaruh paparan karbon monoksida (CO) udara ambien terhadap kadar karboksihemoglobin ( $\mathrm{HbCO})$ dan saturasi oksigen $\left(\mathrm{SaO}_{2}\right)$ pada pedagang di Terminal Arjosari kota Malang. Tesis. Fakultas Kesehatan Masyarakat. Univeritas Airlangga.

8. Selvia, (2011) Hubungan Kadar HbCO dengan Kapasitas Vital Paru Pedagang di Terminal Bus Purwokerto.Mandala of Health Volume 5, Nomor 2. 